\title{
MICRO-UTOPIAS: ANTHROPOLOGICAL PERSPECTIVES ON ART, RELATIONALITY, AND
}

CREATIVITY.

Ruy Blanes, Alex Flynn, Maïté Maskens, Jonas Tinius ${ }^{1}$

\section{Rationale AND CONTEXt}

The editors began discussing this special issue in 2014 through a serendipitous encounter. Ruy and Maïté were interested in the possibility of promoting an anthropology of utopia, and simultaneously an anthropology as utopia. Alex and Jonas, working on anthropological approaches to contemporary artistic practices, were seeking to develop the theorising potential of relational art. The immanent space of connection was, precisely, the concept of "micro-utopia". In our discussions, several questions, problems, and challenges emerged about the relevance of micro-utopias for an anthropology of art in particular, but also for an anthropological agenda concerned with core themes of the disciplines, among them agency, creativity, and relationality.

As editors based in three different continents, we have selected a range of texts that are situated in starkly different fields. We have therefore been faced with challenges of anthropological comparison: how to synthesise distributed anthropological and local expertise? This special issue proposes to render plastic key artistic theories and concepts that help to situate and compare different field sites, with the aim of rethinking core anthropological theory, while also striving to respect the specificities of the contexts and distinct vocabularies of the case studies discussed. In this introduction, we propose a preliminary cartography of the concept of microutopias in art practice and anthropological theory of art. We are, however, wary of sidelining art practice and theory as a sub-discipline or niche area of anthropological inquiry. Instead, we show how micro-utopias - as one example of an ethnographic concept - can feed back into anthropological theory itself and inform some key concepts that have been central to the discipline since its various inceptions.

From an anthropological point of view, framing art as a social experience would be sufficient justification for a disciplinary heuristic construction. The anthropology (or rather, an-

1 University of Bergen, University of Durham, Université Libre de Bruxelles, University of Cambridge. Contact email: ruy.blanes@gmail.com; alex.flynn@durham.ac.uk; mmaskens@ulb.ac.be; jonas.tinius@gmail.com. 
thropologies) of art that we propose goes much further. It entails engaging with art historical and art theoretical themes and concepts, especially if we acknowledge the reflexivity and professional expertise characteristic of the milieus of contemporary art. In this manner, we propose a synthetic way of approaching art, namely as itself a highly reflexive field premised on expertise that can contribute productively to anthropological thinking and practice. This is, we wish to stress, distinct from acknowledging that one is like the other. Instead we suggest that they are "on speaking terms", as suggested by Schneider (2015: 23) following Clifford (1988: 126), and therefore capable of productive dialogue.

As such, this is an interdisciplinary special issue that recognises the specificity of contemporary art practitioners as professionals who produce knowledge and engage with such expertise. Our account therefore presents a perspective regarding certain forms and milieus of artistic production, those characterised by reflection and theorising capacities, links to universities, politics, or markets, and an interest in the contemporary - be it through forms of production that are laboratory- or experiment-based or through a link to our present times. On one level, this anthropological perspective on art therefore takes art into its modern chapter, and beyond, in an attempt to update anthropology on what has happened in art practice and theory since the mid-twentieth century (see Svašek 2007). On another level, we also wish to stimulate a discussion with the strong current of anthropological thinking on art that stresses the "making", "crafting", or "experience" of art at the expense of its historicising and theorising potential and interest (see Ingold 2015).

Contemporary anthropologies of art cannot just theorise for their informants. As anthropologists in this field, we are faced with highly reflexive expert interlocutors who put forward their own theoretical agenda, often on similar, if not conflicting, epistemological terrain. Rather than seeing this as a problem or a conflict, we regard such encounters of intellectual observation and theoretical reflexivity as a productive challenge to illuminate the status quo and to anticipate the future of anthropological scholarship (see Boyer 2001, 2008; and Tinius, this issue). Inasmuch as we show how anthropology can both "learn about" the value of artistic concepts from its practitioners and thus "learn from it, and so as to reflect upon and enlarge our own understanding and judgement" (Laidlaw 2014: 214), our project sees links to that of the anthropology of ethics and gender, which developed as a dialogue with theorising agents whose practices are not just alternatives to, but alternatives for us.

We also take inspiration from Roger Sansi's recent contribution to the relationship between anthropology, art, and the gift (2014), to recognise that the study of aesthetics and art theory today no longer has much in common with the "the Western art cult of aesthetics as an ideology" (Gell 1999). Theoretical developments within specific artistic circles and worlds from one of which we borrow the key term of this special issue - have critiqued this cult repeatedly, and rigorously. The notion that "art is a modern form of religion and aesthetics its theology, just as museums are its temples and artists its priests" (Sansi 2015: 67) has been challenged in many ways by artists as much as by art critics, ranging from Adorno's notion of "negative aesthetics" to Duchamp and the Situationist movement, or contemporary forms of institutional critique and laboratory paradigms (see Macdonald and Basu 2007).

As suggested earlier, in addition to updating anthropology to the self-critical and theoretically reflexive milieus of contemporary artistic practice (even beyond taking on "a decidedly modern approach to art", Sansi 2008: 203), we also wish to indicate how the conceptual 
developments in these fields can return to anthropology. One only need think of terms such as "mana", "hau", and "potlatch" to observe how local and specific lexicons of knowledge have made lasting impacts on the anthropological endeavour, far beyond the ethnographic contexts in which they were elaborated (see Graeber and da Col 2011). In this sense, our contention is that certain artistic concepts put forward synthetic analytic propositions that can throw light on key anthropological theories. This does not gloss over the inevitable differences between anthropology and art: anthropological and artistic theory may be on "speaking terms", but as knowledge practices they are still embedded within an "uneven hermeneutic field" (Schneider 2013) and the contributions to this special issue reflect on and explore this. We proceed not by positing similarity, but by exploring productive analogies (see Geertz 1980); and we look to art as a way to reflect back on anthropological theory and practice.

As a point of departure for this conversation, we chose the curatorial proposition of "microutopias" and instances of relational art as an example of a canonised but provocative concept from the artistic field that prompts three principal questions of relevance to this issue and the wider intervention we propose. First, how do artists engage with art theory and therefore how do their negotiations become part of and constitute art as a dynamic theoretical field? Second, how can micro-utopias (as an example of such artistic theorisation) become an analytic beyond what might be considered part of art worlds? And third, how can such dynamic theorisations feed back into anthropological concepts and practice? The framework of this special issue, and the contributions we have assembled, respond to and engage with this concept by throwing light on anthropological thinking about subjectivity, the negotiation of meaning, post-democracy, citizenship and the state, self-cultivation, exchange, and methodology.

\section{Anthropology, UTOPIAS, AND MICRO-UTOPIAS}

The first major challenge of this special issue is thus to expand upon the complicated distinction between the idea of utopia and the concept of micro-utopia, as proposed by the curator and art theorist Nicolas Bourriaud in his book Relational Aesthetics (2002 [1998]). ${ }^{2}$ As we know, the idea of utopia has a long history in Western philosophical thought, predominantly as a concept of political theory, literature, and praxis towards discussions on governance, communal living, and well-being. This conceptual genealogy famously began with Thomas More's Utopia (1516), a debate of political philosophy concerning an "ideal society" (the fictional island of Utopia, located in the "New World") and its political organisation, which is currently seeing a range of recontextualisations in art and anthropology due to its 500th anniversary, including the Somerset House 'Utopia2016: A Year of Imagination and Possibility' series of events in London. More's book thus explicitly inaugurated a field of thought that included a fictional and representational recourse in order to convey an argument towards the possibility of a "new", "different", "alternative" form of commonwealth.

2 Throughout the texts of this issue, as well as in the several references we discuss, the reader may see reference to either "micro-utopias" or "microtopias". In the English translation (2002) of Nicolas Bourriaud's book Esthétique Relationelle (originally published in 1998), the chosen translation is "micro-utopias" - unlike in subsequent discussions by Bishop (2004) and Flynn (2015), for instance. In this special issue we choose to acknowledge both formulas as equally valid. 
However, and perhaps more implicitly, it also advanced a specific literary "genre": that of writing about politics and society using a "proto-ethnographic" style that combines observation and reflexivity, through the words of Hythloday, the narrator who describes the society (see Claeys 2010; Maskens and Blanes 2016). From this perspective, utopia became more than philosophical conceptualisation; it became a method of speculation and part of an artistic range of "technology of the imagination" (Holbraad et al. 2009).

Most evident among 19th century intellectuals, philosophers, and artists, utopia moved beyond the realm of political philosophy to inform practices of artistic creation and creative epistemologies. Dating from its first use in his unfinished Bildungsroman titled Heinrich von Ofterdingen by the influential Romantic author Novalis, the symbol of the blue flower (blaue Blume) has found its way into the writings, for example, of E.T.A. Hofmann, Goethe, or even Walter Benjamin, for whom it represented a quasi-unattainable desire or hope: a utopian feeling or place. Since the 19th century, we have also witnessed for instance the emergence of a utopian literary genre, of architecture and urban design, music, and aesthetic theory. Within this framework, the "art" of utopia is also and simultaneously methodology, heuristics, and politics. Charles Renouvier, the 19th century libertarian philosopher, aptly exemplified this with his theory of "uchronia" (1876), a formulation towards thinking about history not as it happened, but as it did not happen and as it could have happened. This formulation, although produced at the Bureau de la Critique Philosophique in Paris, provoked a particular form of literary imagination: the possibility of alternative temporalities and the speculation of different realities. To be more precise, this is the literary backbone of what would be known in the twentieth century as the genres of Science-Fiction and dystopian fiction, populated by oeuvres such as Looking Backward, by Edward Bellamy (1888), H.G. Wells' A Modern Utopia (1905), or George Orwell's dystopian 1984 (1949).

We can also find similar appearances of utopian imagination in the realm of music theory and production, such as Ernst Bloch's musical philosophy. In The Spirit of Utopia (2000 [1923]), for example, he famously discussed the utopian imagination as central to the act of musical creation (see also Korstvedt 2010; Zabel 1990):

How do we hear ourselves at first? As an endless singing-to-oneself, and in the dance. Both are still nameless. They have no life in themselves, and no one personally gave them form. Where one encounters them, they possess the appeal of every originary beginning. (2000 [1923]: 34-35)

In his cryptic depiction of the "history of music", Bloch makes use of an understanding of utopia as a "drive" that binds imagination and creation. What these various examples illustrate is how utopia, as a political concept, exceeds the realm of political theory, and has become, over the course of the 19th and 20th century, part of realms beyond the political imagination. Modernism, and its relation with modernity (Jameson 2005; Bronner 2012), is a case in point.

Nicolas Bourriaud, a central figure for this introduction and issue, arrives at the concept of utopia very explicitly through a Bourdieusian notion of power and agency (2002 [1998]: 26) and without reference to the above-mentioned genealogies. Stemming from his curatorial work with certain artists of the 1990s, Nicolas Bourriaud proposes the concept of "everyday microutopias" (ibid: 31 ) to conceptualise certain distinct features of art practices, which he describes as collective, relational, and contextualized endeavours, focusing on the concrete inter-relations among artists and audience members (see, in this respect Roger Sansi's Afterword to this issue). These social interstices, he argues, have become the focus of "relational art", whose principles 
of participation and relationality have indeed since become some of the most prevalent notions to describe contemporary art. Bourriaud, in his dual role of art critic and theoretician, surveyed late twentieth century artistic practices and the growing body of socially-based art work to advance a theory of art that takes as its model "the flexible processes governing ordinary life" (2002 [1998]: 47). In his programmatic work on the subject of what he calls "relational aesthetics", he elaborates various definitions of art practices that are inherently relational, because they pose a perspective on art that is "taking as its theoretical horizon the realm of human interactions and its social context” (ibid: 14).

Bourriaud's proposal did not emerge from a vacuum; he reacted explicitly against mainstream interpretations of art that either framed it as a product of an individual imagination or within wider macro-temporal movements and trends (e.g. baroque, neoclassical, etc.). As others before him, his work took place in a "tradition" of French social thought (from Fourier, to André Breton and the Situationist International) reacting against abstract utopianism by proponing concrete actualization of the utopian impulse into everyday life but also against an aleatory frontier between art and the everyday (see Gardiner 1995). He also understands relational art as a critique of the objectification of social relations, which he attests to the late twentieth century; artworks that focus on the creation of concrete instances of intersubjective and social encounters, in his view, arguably provoke a glimpse into a democratic, "micro-utopian" space. Inspired by philosopher Félix Guattari's ideas of micropolitics and politics of proximity, as well as by the Marxian notion of social interstice, Bourriaud framed relational aesthetics as a process of creation that takes the creation of social encounters into the sphere of the otherwise private encounter with art-objects in an art gallery of museum. ${ }^{3}$ Art is thus a social means and end, and is not confined to artists themselves, or the objects they produce. Bourriaud's concern was therefore one that could allow for a critical understanding of art practice within a situated, historically, and politically informed context. Moreover, from this perspective, relational art becomes legible as a "social environment". Within this framework, micro-utopias appear as (artistic, political) statements that result from the "neighbourhood interactions" of our everyday lives, from the ability to imagine and create in the local sphere, responding to concrete political questions of the present. Bourriaud is thus interested in utopia as a "device" to move away from the abstract and locate the concrete, political component of the micro-dimension of social life, the structures and flows of power and production that conform our everyday lives:

This is what I call utopias of proximity, those apparently anonymous operations that relate to elements of everyday life, but which clearly and forcefully reveal the power relations, the relations of production. (La Chance 2002: 43; our translation)

Bourriaud's notion of utopias of proximity thus reveals an interesting anthropological concern with the concrete, the material and the everyday. This micro-realm is thus one of emergence and concretisation of utopias, which are located in a space of concrétude, instead of a commonsensical space of an unreal ideal. From this perspective, Bourriaud appears close to what other researchers of utopia have defined as "real utopias" (Wright 2009), "everyday utopias" (Cooper 2014), or even "nowtopias" (Carlsson \& Manning 2010). So, instead of thinking in terms of imagined Shangri-las, Vallhallas, or Waldens, Bourriaud points, through Guattari's microscopic, molecular (1977) angle, towards the community and neighbourhood as spaces where utopias can be actualised (2002: 31). However, Bourriaud seems less interested in defining the space of

3 It should be noted that his intervention is still firmly located in a rather uncritical take on institutional authority - a position that has been critiqued elaborately by Néstor García Canclini (2014). 
utopian relationality as a prefiguration, but instead, as an interstice, a transience into a context of creation and poïesis (2002: 70). Thus, utopia becomes fundamentally an expression of practical politics, as we will discuss further below.

Bourriaud's microcosmic utopia also unearths the problem of the "art" of events and their role in social life. Whereas art is oftentimes framed in terms of concretising moments (events, performances, artefacts, objects), thinking through interstitial relationality pushes us into rethinking their role within the process of creativity. Thus, if the contributions included in this special issue initially refer to "productions" - theatre plays, film-making, musical shows, exhibits -, they also go beyond the analysis of such productions "in their own terms", depicting the sociality of artistic interaction, thus contributing to an emerging anthropology of creation and creativity that goes beyond art (Pandian 2015).

Bourriaud's concepts of micro-utopias and relational aesthetics are "good theories". But they are good not because of the correctness of their content (obviously subject to debate), but in the sense proposed by Claude Lévi-Strauss in his The Savage Mind (1962). They are good to think with, because of the reactions, reflections, and critique that they spurred, not only in art theory (see e.g. Bishop 2004), but across disciplines. In this special issue, we pick up on the emerging debate concerning relational aesthetics within anthropology (Sansi 2014; Flynn 2015), focusing on the notion of micro-utopias as a case in point. We challenged anthropologists working on art and creativity to see how they would react to Bourriaud's concept in the framework of their own ongoing ethnographic studies, inherently relational in their essence (Maskens and Blanes 2016). Such an endeavour, in any case, requires further reflection on what is understood by "relational art" within the wider spectrum of contemporary art practice.

\section{Cartographies of relational art}

The concept of the micro-utopia as elaborated by Bourriaud in Relational Aesthetics is embedded within specific art historical understandings of participatory art practice. An important starting point is Hal Foster's understanding of "the artist as ethnographer" (1996) - later popularised as "the ethnographic turn" in contemporary art (see Siegenthaler 2013). Through its emphasis on subjectivities and communities beyond institutional spaces, Foster's theoretical approach has been located as an important precursor, but also analytic, of what has variously been termed social, relational, participatory, community, or activist art (Foster 1996). Tom Finkelpearl (2014) foregrounds a different perspective on the genealogy of the participatory, highlighting the political processes that engendered mass mobilisation around civil rights and feminism, and the connections therein to aesthetic realisations and instantiations of these struggles. Grant Kester echoes Finkelpearl's emphasis on extra-institutional collectives seeking change, arguing that the collaborative practices often associated with participatory art have "performed a defensive function" (2011: 4) against a hostile and reactionary art establishment since the 1960s. Citing Situationist International as an example, Kester suggests that such groups built on the collective traditions of the interwar years, as enacted by the Dadaist and Surrealist movements, a connection that Sansi elaborates in his recent book on anthropology, art, and the gift (2015). Claire Bishop focuses similarly on interventions that proposed political reconfiguration, although she widens her focus to include actions and programmes that were directly or indirectly associated with the state. In Artificial Hells (2012), Bishop's analysis centres on three particular 
moments in the European avant-garde: Italian Futurism; post-1917 Russia; and André Breton's Paris Dada (2012: 41). For her edited collection Participation (2012), however, the cover pointedly displays an image of "Baba Antropofágica" a work by the Brazilian artist Lygia Clark. This connection to Brazil's Neo-concrete movement is important to the trajectory of participatory art, as artists such as Hélio Oiticica and Lygia Clark's body of practice has created a longstanding interest in how the spectator as agent can engage with art objects. Clark's series of Bichos, created in the early 1960s, places a particular responsibility on the viewer of an art object to become an interactive agent, destabilising the porous boundaries that are the subject of this collection. However, perhaps one of the most interesting analyses of the "social turn" in contemporary art has been put forward by Shannon Jackson, in her insistence that such works have a "fundamental interest in the nature of sociality" (2011: 2). Jackson's reading encourages us to analyse such "post-optical" object making through the lens of performance: art thus becomes "a site of group coordination in space and over time" (ibid: 3 ).

In this very brief cartography, what becomes clear is an art historical preoccupation with classification and in some senses, appropriation, of what can, and what cannot be considered as an art object worthy of consideration. Such categorisations are freighted with judgments: "community art" has long been relegated beneath other practices, almost to the level of "artisanal" practice, a long way distant from "conceptual" works which can be legitimately made part of museum's collections. Such categories and valorisations are not our focus in this special issue, and as Alex Flynn's discussion of Liberate Tate's The Gift makes clear, the extent to which inclusion in a canonical art historical tradition is welcome, or indeed, sought, by practitioners of participatory art is debatable (see Flynn, this issue).

In his entry on "Participatory Art" for the Encyclopedia of Aesthetics (2014), Tom Finkelpearl argues for a broad three-way division: relational, activist, and antagonistic. He proposes that although there are important differences between, respectively, the artist Rikrit Tiravanija cooking Pad Thai in an art gallery Untitled (Free) (1992), instances of citizens taking the initiative to create an architectonic intervention in their neighbourhood, and Santiago Sierra's $250 \mathrm{~cm}$ line tattooed on 6 paid people (1999), what links these works is the idea that what is at stake is the possibility of intersubjectivity and the instantiation of relations. While Finkelpearl's categorisation is extremely helpful, what is important in any anthropological analysis of such diverse art objects and practitioners, (as opposed to art historical categories) are questions that relate to sociality: for example, notions of instantiation; axes of verticality and horizontality; political intention; and/or modes of practice/work. Here we propose three heuristic categories premised on dimensions of conceptualisation and realisation, each producing different kinds of relations and meanings, that foreground how participatory art experiments can differ, irrespective of their art historical status.

The first dimension includes works that can be thought of as characterising Bourriaud's paradigm of relational aesthetics or equally the more "antagonistic" practices described by Claire Bishop. These projects are conceived of by an individual but rely on the presence of a group of people to activate the work. Liam Gillick's oft-quoted comment on his practice makes this clear:

My work is like the light in the fridge. It only works when there are people to open the fridge door. Without people, it's not art - it's something else - stuff in a room. (Gillick 2000: 16) 
Note the emphasis here on Gillick's possessive pronoun "my". The work remains his, despite the fact that without the activation of other people it is just "stuff in a room". This question of authorship is important as it foregrounds an obvious tension between dimensions of creativity: the work is conceptualised individually, but activated collectively. Notwithstanding, the credit, percentages, and other facets of authorship remain with the artist-conceiver.

A second dimension can be drawn precisely from the idea of the act of conceptualisation. While Gillick puts forward a work that is "his", contractually, intellectually, and emotionally, much participatory art is developed through networks and collaborations with curators, collaborators, and artist-peers. The notion of a "pure" individual creation, a persistent and most recently Romantic ideology, puts forward creativity as the "solitary, ex nihilo creation of products of self-evident and universal value - most emblematically in the field of art - by highly exceptional and gifted individuals"(Wilf 2014: 398). This concept, which became a founding stone of Western art institutions is now largely disregarded in the anthropological literature. However, as a discourse, it persists in contemporary art criticism and curatorial practice: the apocryphal account of Charles $V$ kneeling to receive Titian's brush at the artist's atelier is well mobilised by Grant Kester in his examination of this paradigm, highlighting the celebrity and aura that has embedded itself in understandings of artistic practice and creation (2011:3). As such, we do not wish to suggest here that art projects can be conceived of entirely "individually" as in the first dimension, but the inclusion of multiple actors into processes of conceptualisation is a question of degree and foregrounds the notion of a distributed creativity, mobilised at the stage of planning of the work (see Schuiling and Tinius, this issue). In this second dimension, these projects, may or may not have activist connotations, but through discussion groups, seminars, lectures, and instances of the autonomous university that characterises active contemporary art scenes, an idea may be developed, shared, commented on and revised, before being realised, again by an individual, depending on the activation of a collective.

The third dimension extends this idea of distributed creativity to its logical extent: the inclusion of the collective. In this understanding a work is conceptualised, but also realised collectively by the same people. In this manner, the dynamics of the activation of the work are embedded in how the work has been created, resulting in a hierarchy of decision making that may be more horizontal and open to diversity than the first two dimensions. Although this model may be identified with "community art" projects, it can also be localized in the work of artists or projects with more openly activist intentions, like Artúr van Balen, who was invited to work in collaboration with activist groups during the general strike in Barcelona in 2012. In groups of collective decision-making, thinking through what might represent an apt symbol of protest eventually resulted in a huge inflatable cobblestone. In the street protests that followed this object played on the interstice between interactivity, public sculpture and an aestheticised politics, being activated by the same collective (and others) who had participated in its conceptualisation and construction. In this manner, a horizontal framework of decisionmaking emerges and the consequences for the relations and meanings that are produced from such a process provides a pathway to a more anthropological analysis. This brief cartography serves merely to contextualise the specific placing of relational, or participatory art theory that underlines the contributions to this volume. In the following articles, the tensions surrounding hierarchy, creation and the creator/activator will become clearer, and we hope that this may lead to further work on this topic. 


\section{WhAT KINDS OF RELATIONS?}

In his programmatic book Relational Aesthetics, Bourriaud defines "relational (art)" as:

A set of artistic practices which take as their theoretical and practical point of departure the whole of human relations and their social context, rather than an independent and private space. (Bourriaud 2002 [1998]: 113)

The attested focus of these art practices and their theoretical conceptualisation, from which we draw the core notion of this special issue, is explicitly human-focused, leaving aside and deliberately going beyond a vision of art as object or material. One of the obvious questions that could be levelled against Bourriaud's understanding of relations, thus, is that it neglects the complex composition of relationality and distributed agency (see Gell 1998). As Marilyn Strathern has pointed out in a variety of contexts $(1995 ; 1996)$, relations and networks are composed of a variety of objects, people, and ideas, many of which have differentiated agencies. As she writes, in dialogue with Bruno Latour's suggestion of sociology as the "tracing of associations" (2005: 5):

A network is an apt image for describing the way one can link or enumerate disparate entities without making assumptions about level or hierarchy. Points in a narrative can be of any material or form, and network seems a neutral phrase for interconnectedness. (Strathern 1996: 522)

The human (body), for her, counts as one such "'network' of materials ... for it gives off diverse signals, revealing skill, charisma and pathology" (ibid: 520). Different from ActorNetwork Theory, however, she is interested in noting that relations are not just endlessly and effortlessly created; they are mediated, hierarchically ordered, and even severed, or "cut". Indeed, as with the term network, the notion of a relation also "seems a neutral phrase for interconnectedness" (ibidem, p. 522).

If relations are not only composite and hierarchical, but also mediated and subject to different orders of control, then surely the question that should be posed to relational artworks is: what kind of relations are created in such an aesthetics? What kind of relations and subjectivities are facilitated or inhibited in specific "micro-utopian" encounters? In his article on the cultivation of fictional characters in refugee theatre, Jonas Tinius raises a number of similar challenges with relational aesthetics, demanding that we subject it to an ethnographic interrogation. As anthropologists, he argues, we are trained to observe and qualify the complex nature of relationality and the constitution of subjectivity, and it is in the experimental settings of rehearsals and other creative social processes that we can observe, challenge, and revise theories of relationality through art. He also connects the conversation on "relationality" with an emerging anthropological discussion on detachment, distance, and reflection - concepts that have long been central to understanding artistic creation (see Adell 2016; Candea et al. 2015).

For Bourriaud, relational art practices are a reaction against a specific change in the way (western) society organises relations in the late twentieth century. "These days", he writes, "the social bond has turned into a standardised artefact" (Bourriaud 2002 [1998]: 9). In Western capitalist society today, Bourriaud claims, "human relations are no longer 'directly experienced" (ibid.). Therefore, "the most burning issue" for contemporary artists would have to be whether "it is still possible to generate relationships with the world" (ibid.). Driven by scepticism about the experience of intersubjective relations and the arguable commoditisation of subjectivity - an argument that is inspired explicitly by his aforementioned relation to the philosophy of 
Guattari - Bourriaud "observes" that "artistic praxis appears these days to be a rich loam for social experiments" that work towards creating "hands-on utopias"(2002 [1998]: 9). This relates to observations made in other fields of art history and theory, such as Shannon Jackson's insistence on the interest in "the nature of sociality" (2011:2) discussed in the previous section. What renders Bourriaud's observations both problematic and intriguing is that he redirects art back to fundamental questions beyond art. Artistic practice, in a move not coincidentally echoing Situationist and Fluxus, focuses on realms that are beyond itself, which try to move the scope of art beyond its definitional realm, to dissolve the boundaries framed for it within institutional and disciplinary settings.

It will strike most readers as paradox that an artistic movement or paradigm that emerged within particularly powerful western institutional traditions - defined by a particularly powerful western institutional figurehead and critic - should have as its focus the dissolution of such frames. The critic who has most aptly captured this problematic side of relational aesthetics is CUNY professor of art history Claire Bishop. She questioned the supposedly "democratic concern that informs [relational art]" (Bourriaud 2002 [1998]: 57), arguing that the "temporary collective form that it produces" (ibid: p. 61) is not a sphere of "sphere association" (ibid.), but one of hierarchy and power. She noted that when we look at so-called relational, social, or participatory art today, it is not enough simply to posit the production of relations or encounters; we ought to ask what kinds of relations they engender. Who is the subject or agent? Who the recipient or pawn played in an institutional context? What forms of participatory oppression, scripted social cohesion, or "artificial hells" may it provoke (Bishop 2012; Cook and Kothari 2001)?

\section{THE PROBLEM OF CREATIVITY}

As an art critic, Bourriaud is, we believe, ultimately interested in a theory of creativity that addresses the process of artistic creation and production. Within this framework, his invocation of the concept of utopia into micro-utopias responds not only to a concern with politics, but also with a dimension of imagination, fabric, and production. From this perspective, relational aesthetics has important theoretical implications for classical anthropological fields of enquiry such as personhood, agency, and relationality. As suggested above, Bourriaud's concern with proximity and micropolitics not only embeds artistic processes into the social, but also shifts the locus of creativity into the social process.

From this particular perspective, Bourriaud's theory speaks to Alfred Gell's theories of art (1998) insofar as they conceptualise art objects as embedded in a nexus of social relations. However, here there is a lesser concern with the material objects and artefacts per se, which may be an outcome of artistic agency, but instead, as discussed in the previous section, with the people and the effects of the relationships they build in collective contexts. From this perspective, Gell's theory of creativity refers to art and art making, but in performative terms, as actions and productions that affect and change the agents involved (through virtuous technique and abduction) rather than just replicating and encoding it through symbolic propositions. Art and art objects are thus seen on par with the persons that create and appreciate them, from creators and prototypes to basically "everywhere" (1998: 35), and thus constitute undetachable processes. And precisely, such forms and materialities emerge and incorporate agency from the creativity 
of social life, that which can be observed in the micro-politics of the everyday.

Here, we are tempted to see such socialized creativity as what Ingold and Hallam (2008) described as "improvisation", the generative, relational, transitory and productive way in which "people (...) work it out as they go along" (2008: 1). From their perspective, social life is embedded with "improvisational creativity", by which imagination and performance become a conjunction towards our perception of life as constantly "in the making". While we find it easy to agree with this proposition that envelopes life with dynamics and transformation, and we embrace the co-participatory character of improvisation, we are also interested in art forms and expressions as intentional productions of voluntary association and creations of proximity. Here, universes of meaning become historical, contextual, oftentimes genealogical. This is the case, for instance, of the Dutch improvising musical collective known as Instant Composers Pool, discussed by Floris Schuiling (this issue), which was founded in the mid-1960s very explicitly as a "counter-culture". It is also the case of art-making initiatives designed as forms of community-making in post-disaster L'Aquila in Italy, described in this issue by Jan-Jonathan Bock.

In sum, we are interested in a middle ground between conceptions of art and creativity as commodified, impersonal productions, and, on the other hand as pure, unintentional improvisations. Bourriaud's micro-utopia offers this possibility, precisely because it also allows us to incorporate the utopian element of art as a "process", and simultaneously locate it within historical and political contexts. In this respect, Richard Howells (2015) suggested, following Ernst Bloch, that our expectations and prospects of "better worlds yet to come" (2015: 1) are embedded not in political tracts, but in art, literature and popular culture (see also Jameson 2005) and as such in actualised, albeit fictional, realities. Howells notes in addition that the location of the "wishful" in our everyday lives appears not so much in artistic genre, representation or figuration, but instead in "design", in the process of the materialisation of imagination.

\section{The PROBlem of POLitical AgenCy}

As stated above, Bourriaud's elaboration of micro-utopias incorporates an explicit understanding of art practices as agentive political, both in terms of their materiality and potential:

How is it possible to transform the world from scratch and rebuild a society which would be totally different? I think that is totally impossible and what artists are trying to do now is to create micro-utopias, neighborhood utopias, like talking to your neighbor, just what's happening when you shake hands with somebody. This is all super political when you think about it. That's micro-politics. ${ }^{4}$

Anthropologists of art and performance have long identified this political configuration. Turner and Schechner's theories of performance were informed by notions of social drama, implying the recognition of the rituality, spectacle and audience factors of artistic creativity, to the extent of a speculation around the idea of the "anthropology" of performance - not as a disciplinary approach to performance, but understanding performance in itself as a form of "anthropology" (see Turner 1987), a poetics or poïesis that is inevitably enveloped in history and politics. This is the case debated by one of the contributors to this volume, Sophie Reichert, in

4 In http://www.stretcher.org/features/nicolas_bourriaud_and_karen_moss/. Retrieved 27 January 2016. 
her discussion of the performative production of "archives" in Chicago. From this perspective, we can think of Guy Debord's Situationist manifestos as a case in point in what concerns ideas of "intervention" and "protest" as part of the economy of the art world. More recently, we have the interesting case described by Alexei Yurchak (2008) on the "inevitability" of politicized art, in his discussion of the "politics of indistinction" in late Soviet Russia.

However, to claim that art is politics is not much more than stating the obvious. What is more interesting is to enquire in what terms this is so. Jonas Tinius' contribution to this issue addresses this critique through an ethnographic case study on the cultivation of a detached subjectivity in refugee theatre rehearsals. He does so by recourse to one of the major critiques raised against Bourriaud's theory from art historian Claire Bishop (2004), who noted the absence of plurality and antagonistic politics in her discussion of relational aesthetics. Bishop argued that these art practices do not produce democratic relations but instead build on mechanisms of exclusion that don't address the antagonism and inequality in the process of art production pertinent to "the divided and incomplete subject of today" (2004: 79). Furthermore, one cannot propose a political approach without qualifying in what terms this politics is played out. In other words, a micro-approach requires an invitation to the concrete, and Alex Flynn's analysis of contemporary art interventions takes up the Bourriaud - Bishop debate, arguing how Bishop's "concrete", or rather, "antagonism" might itself limit plurality (this volume). Roger Sansi has also addressed this debate in his book Art, Anthropology and the Gift (2014), albeit from a different perspective, in criticizing Bourriaud's insertion of utopia "within" art - thus removing its political agency, in contradiction with the micro-utopian project in itself - and advocating the indistinction of art and life (2014: 157). To demonstrate this, Sansi incorporates the problem of "crisis" as it emerged within the European Union project, once the utopian space of "collective experimentation" (Latour 2011) but now, as Sansi proposes, a scenery of movements and processes that unfold "prototypes" (Corsín 2013), new ways of imagining and acting upon the world.

Our point, however, is not just of rendering the politics of art, but also the art of politics, understood sensu lato, in our micro-political everydays. This is precisely what Davina Cooper explores in her book Everyday Utopias: "networks and spaces that perform regular daily life" (2014: 2). This performance is artistic inasmuch as it "opens up" possibilities for new social configurations, new expectations and temporalities, new materialities. As with Sansi's and Bourriaud's proposals, it is the experiment that opens the space for transformative politics, oriented towards more egalitarian, liberated, free, democratic lifestyles. This is the work of art and the work of utopia.

\section{CONTRIBUtions AND STRUCtURE OF THE SPECIAL ISSUE}

In his article "Rehearsing Detachment", the anthropologist Jonas Tinius takes us into the rehearsal processes for a critical interactive and site-specific refugee theatre project in the postindustrial German Ruhr Valley. His contribution responds to Nicolas Bourriaud's account of the poetic function of relational art, which according to relational aesthetics "consists in reforming worlds of subjectivization" (2002 [1998]: 104). Tinius challenges and complements this account by providing an ethnographic description of what he terms "dialectical fiction". This notion describes actors' cultivation of detachment and reappropriation of subjectivity dur- 
ing theatre rehearsals by building up fictional characters. By inviting refugee actors to introduce abstract and fictitious characters into their reflections on acting and cultivation of an acting conduct, the project he discusses aspired to what its director called theatre's "impossible political utopia": a situation in which refugees are not framed as "authentic" vulnerable victims "acting themselves", but as creative agents capable of playfully negotiating their political subjectivities in a collectively reflected context of social creativity.

The trained musicologist Floris Schuiling, who conducted fieldwork on musical creation, offers a critical take on relational aesthetics from the perspective of "relational musicology". Discussing the emergence of this relatively new field at the intersection between musicology and ethnomusicology, Schuiling argues that it shares fundamental concerns with relational aesthetics, first and foremost the question: how do artistic and musical practices shape social relations? His article elaborates the role of "utopia" in music theory and scholarship, submitting the notion of creativity and improvisation to a critique of Bourriaud's concept of micro-utopia. Schuiling's intervention is based on an ethnographic research project on the Instant Composers Pool Orchestra, an improvising collective based in Amsterdam that has built a global reputation as one of the most innovative groups in improvised music. In his analysis, he raises questions about the extent to which music as a social practice, the institutions and social organisation of art music, and the hierarchies and forms of interaction present in particular musical practices dominated the activities of both composers and improvising musicians, attending to the role of hierarchy and authority in supposedly "free" creative settings.

Alex Flynn's article analyses the notion that social movement politics and contemporary art interventions increasingly traverse a porous boundary, be it in terms of practices, relations, or institutions. The chapter highlights remarkable resonances between the paradigm of relational aesthetics and the ethnography of prefigurative and antiauthoritarian direct action politics, before moving to initiate a dialogue with politically engaged artistic experiments in São Paulo. The chapter argues that an analysis that foregrounds ephemerality, the "absolute centrality of diversity", and different forms of dissonance, allows us to grasp how subjectivity is elaborated and meaning created in the increasingly shared micro-utopias of social mobilisation and contemporary art.

Anne-Sophie Reichert focuses ethnographically on a performance art group (Every house has a door, from Chicago) to incorporate a further element of discussion in what concerns relational art: its diachronicity, and the place of memory, archive and temporality in the recognition of (radical) political potential in performance. Using the body as locus, she suggests that relationality, while exceeding self-contained individuality, can also exert normativity and therefore political statement through "encounter-based collaboration" - echoing Anna Tsing's recent monograph (2015). Her conclusion is that we need to understand the conditions and protocols through which collaborative worlds emerge.

Jan-Jonathan Bock illustrates this conundrum in his analysis of artistic creation in postdisaster contexts. He focuses specifically on the region of L'Aquila, devastated by a massive earthquake in 2009, describing how art became part of the "cultural work" devised for the recovery of local inhabitants. If on the one hand, there was a political movement towards the use of communitarian artistic projects to deal with individual and collective distress, on the other, the kinds of artistic engagements that took place actually produced new forms of experience that focused more on ideas of enduring relationships and collective recovery, beyond the "obvi- 
ous" ritualised, event-based production. This becomes an interesting utopian alternative to the mainstream, enjoyment-based cultural production that characterises contemporary art.

Neylan Bağcioğlu takes this last point as a central problem in her article: the self-referential and provocative nature of stances of struggle against industrial or industrialized art. This is the case of Ahmet Öğ̈ut's intervention "Intern VIP Lounge", held in the Dubai Art Fair in 2013, which she discusses in detail. Her goal is to investigate the very utopian problem of artistic labour, and how it may, or may not, be conceived as an expression or manifestation of utopian worldview, either through ideologies of community, egalitarianism, and solidarity.

Alexandrine Boudreault-Fournier's chapter reframes the notion of the micro-utopia by presenting and analysing a virtual space through which artists are brought together and relations are elaborated. Through a series of video clips, in which musicians who have never met or worked together before collaborate, the chapter highlights the bearing of a virtual, distanced, and spatial reading of the relational aesthetic paradigm. In discussing the nature of these distant relations provoked by an anthropologist during the production of a project that aims to create points of connections between communities, the chapter also puts forward an innovative methodological proposition that is significant for the wider discipline.

Finally, the contribution by Adolfo Estalella and Tomás Sánchez Criado offers a "hands on approach" of relational practices, by taking the ethnographic endeavour in itself as a space of experimentation and collaboration. Using abundant irony and humour, Estalella and Sánchez Criado produce an ethnographic object named "Antropocefa", a kit that promises to solve the anthropologist's anxieties and moments of social participatory awkwardness in the course of his or her research. We are not given a price for this panacea, but we are given the opportunity to see, through such devices and productions, the artistic and relational dimensions of ethnographic work.

Together, these pieces enable a field of reflection within anthropology that we hope can be continued in subsequent occasions: the anthropology of art and creativity and the anthropology of utopias.

\section{References}

Adell, Nicolas. 2016. “Des vies créatives”, L’homme 2016/1 (216): 109-122.

Bishop, Claire. 2004. “Antagonism and Relational Aesthetics”, October 110: 51-79. 2006. Participation. London: Whitechapel Gallery. 2012. Artificial Hells. London: Verso.

Bloch, Ernst. 2000 [1923]. The Spirit of Utopia. Stanford CA: Stanford University Press. 1988. The Utopian Function of Art and Literature: Selected Essays. Cambridge MA: MIT Press.

Bourriaud, Nicolas. 2002 (1998). Relational Aesthetics. Dijon: Les Presses du Réel.

Boyer, Dominic. 2001. "Foucault in the Bush: The Social Life of Post-Structuralist Theory in East Berlin's Prenzlauer Berg”, Ethnos 66 (2): 207-236.

2008. "Thinking through the Anthropology of Experts", Anthropology in Action 15 (2): 38-46. 
Bronner, Stephen Eric. 2002. Modernism at the Barricades. Aesthetics, Politics, Utopia. New York: Columbia University Press.

Canclini, Néstor García. 2014. Art beyond Itself: Anthropology for a Society without a Storyline. Durham, NC: Duke University Press.

Candea, Matei, Joanna Cook, Catherine Trundle, and Thomas Yarrow (eds). 2015. Detachment: Essays on the limits of relational thinking. Manchester: Manchester University Press.

Carlsson, Chris and Francesca Manning. 2010. "Nowtopia: Strategic Exodus?”, Antipode 42 (2): 924-953.

Claeys, Gregory. Ed. 2010. The Cambridge Companion to Utopian Literature. Cambridge: Cambridge University Press.

Clifford, James. 1988. The Predicament of Culture. Cambridge, MA: Harvard University Press.

Cook, Bill and Uma Kothari. 2001. Participation. The New Tyranny? London/New York: Zed Books.

Cooper, Davina. 2014. Everyday Utopias. The Conceptual Life of Promising Spaces. Durham/ London: Duke University Press.

Corsín Jiménez, Alberto. 2013. "Introduction: The Prototype: More than Many and Less than One", Journal of Cultural Economy (online first).

Finkelpearl, Tom. 2014. "Participatory Art". In Encyclopedia of Aesthetics, Michael Kelly (ed.). Oxford: Oxford University Press, n. pag.

Flynn, Alex. 2015. "Re-Imagining Political Subjectivities: Relationality, Reflexivity, and Performance in Rural Brazil”. In Flynn, Alex and Jonas Tinius (eds.), Antbropology, Theatre, and Development. The Transformative Potential of Performance. London and New York: Palgrave Macmillan, 33-53.

Foster, Hal. 1996. The Return of the Real: The Avant-Garde at the End of the Century. Cambridge, MA: MIT Press.

Gardiner, Michael. 1995. "Utopia and Everyday Life in French Social Thought", Utopian Studies, 6 (2): 90-123.

Geertz, Clifford. 1980. Negara. The Theatre State in Nineteenth Century Bali. Princeton, NJ: Princeton University Press.

Gell, Alfred. 1998. Art and Agency: An Anthropological Theory. Oxford: Oxford University Press. 1999. The Art of Anthropology: Essays and Diagrams. London: LSE Monographs/ Bloomsbury.

Gillick, Liam. 2000. Renovation Filter: Recent Past and Near Future. Bristol: Arnolfini.

Graeber, David and Giovanni da Col. 2011. "Foreword: The Return of Ethnographic Theory", HAU: Journal of Ethnographic Theory 1 (1): vi-xxxv.

Guattari, Felix. 1984. Molecular Revolution. London: Peregrine.

Holbraad, Martin, Morten Axel Pedersen, and David Sneath. 2009. "Technologies of the Imagination: An Introduction", Ethnos. 74(1): 5-30.

Howells, Richard. 2015. A Critical Theory of Creativity. Utopia, Aesthetics, Atheism and Design. London/New York: Palgrave.

Ingold, Tim. 2015. "Ethnography is to Anthropology as Art History is to Arts Practice: A Provocation". Unpublished Frank Davis Memorial Lecture. The Courtauld Institute of Art, London. 10 November 2015. http://courtauld.ac.uk/event/ethnography-is-to-anthropology-as-art-history-is-to-arts-practice (last accessed, 26 February 2016).

Ingold, Tim and Elizabeth Hallam. 2008. "Creativity and Cultural Improvisation: An Introduction", in Hallam, Elizabeth and Tim Ingold (eds.), Creativity and Cultural Improvisation. Oxford/New York: Berg, 1-24. 
Jackson, Shannon. 2011. Social Works: Performing Art, Supporting Publics. New York: Routledge.

Jameson, Fredric. 2005. Archaeologies of the Future. A Desire Called Utopia and Other Science Fictions. London: Verso.

Kester, Grant. 2011. The One and the Many: Contemporary Collaborative Art in a Global Context. Durham, NC: Duke University Press.

Korstved, Benjamin. 2010. Listening for Utopia in Ernst Bloch's Musical Philosophy. Cambridge: Cambridge University Press.

La Chance, Michaël. 2002. "Les Utopies de Micro-Proximité: Entretien avec Nicolas Bourriaud”, Spirale: Arts, Lettres, Sciences Humaines 182: 41-43.

Laidlaw, James. 2014. The Subject of Virtue: An Anthropology of Ethics and Freedom. Cambridge: Cambridge University Press.

Latour, Bruno 2005. Reassembling the Social. An Introduction to Actor-Network-Theory. Oxford: Oxford University Press. 2011. "From Multiculturalism to Multinaturalism: what rules of method for the new socio-scientific experiments", Nature and Culture 6 (1): 1-17.

Lévi-Strauss, Claude. 1962. La Pensée Sauvage. Paris: Plon.

Macdonald, Sharon and Paul Basu (eds). 2007. Exbibition Experiments. Oxford: WileyBlackwell.

Maskens, Maïté and Ruy Blanes. 2016. "Introduction: Ethnography and the Mutualizing Utopia", Journal of the Anthropological Society of Oxford (forthcoming).

More, Thomas. 2009 [1516]. Utopia. In Three Early Modern Utopias. Ed. Susan Bruce. Oxford: Oxford University Press.

Pandian, Anand. 2015. Reel World: An Anthropology of Creation. Durham: Duke University Press.

Renouvier, Charles. 1876. Uchronie (l'Utopie dans L'Histoire). Paris: Bureau de la Critique Philosophique.

Sansi, Roger.2008. "Review of: Svašek, Maruška. 2007.Anthropology, Art and Cultural Production. London: Pluto Press", Journal of the Royal Anthropological Institute 14: 201-235. .2014. Art, Anthropology and the Gift. London: Bloomsbury.

Schneider, Arnd. 2013. "Contested Grounds: Fieldwork Collaborations with Artists in Corrientes, Argentina”, Critical Arts 27 (5): 511-530.

. 2015. "Towards a New Hermeneutic of Art and Anthropology Collaborations". EthnoScripts 17 (1): 23-30.

Siegenthaler, Fiona. 2013. "Towards an Ethnographic Turn in Contemporary Art Scholarship”, Critical Arts: South-North Cultural and Media Studies 27 (6): 737-752.

Strathern, Marilyn. 1995. The Relation: Issues in Complexity and Scale. Chicago: Prickly Pear. .1996. "Cutting the Network", Journal of the Royal Antbropological Institute 2 (3): 517-535.

Svašek, Maruška. 2007. Anthropology, Art and Cultural Production. London: Pluto Press.

Tsing, Anna L. 2015. The Mushroom at the End of the World. On the Possibility of Life Beyond Capitalist Ruins. Princeton NJ: Princeton University Press.

Turner, Victor. 1987. The Anthropology of Performance. New York: PAJ.

Wright, Erik O. 2009. Envisioning Real Utopias. London: Verso.

Yurchak, Alexei. 2008. "Necro-Utopia. The Politics of Indistinction and the Aesthetics of the Non-Soviet”, Current Anthropology 49 (2): 199-223.

Zabel, Gary. 1990. "Ernst Bloch and the Utopian Dimension in Music", The Musical Times 131 (1764): 82-84. 